\title{
Os "Abutres" na turbulência das "Águias": Tavares Bastos, a Questão Bancária e os embates do Gabinete Olinda
}

Eide Sandra Azevedo ABREU

Resumo: Este artigo enfoca a relação entre as dificuldades encontradas pelo gabinete Olinda, no ano de 1866, e as lutas que no interior do mercado aconteciam em torno de um encaminhamento para a "questão bancária". Com base em pesquisa feita no Jornal do Comércio e no Correio Mercantil, bem como nos Anais da Câmara dos Deputados e do Senado, demonstra que membros do gabinete estavam ligados a grupos de negociantes com interesses específicos em relação a esta questão.

Palavras-chave: Liberalismo - Brasil - Séc. XIX; Brasil - História - Império, 1822-1889; Questão bancária - Brasil - Séc. XIX.

Agora já não há mais saquaremas, nem luzias, nem ligueiros. Os saquaremas chamam-se vermelhos, os luzias históricos, e os ligueiros papelórios. Viva o progresso! (Jornal do Comércio, 13 de junho)

O dinheiro não regorgita, mas abunda na praça; o que não abunda é a confiança, a qual fugiu espavorida. (...) (Jornal do Commercio, 22 de abril de 1866, p. 1)

- Professora Doutora do Departamento de Ciências Sociais Universidade Estadual de Maringá - UEM - 87030-030 - Maringá Paraná - Brasil. E-mail: eideabreu@uol.com.br 
Tenho, Senhor Presidente, mostrado que realmente o papel-moeda é uma verdadeira peste circulante. Só há uma desculpa: quem nos deu a guerra deve dar-nos o papel-moeda, deve dar-nos a peste. (Jequitinhonha, em discussão de 9 de agosto de 1866, no Senado)

As relações entre a dimensão do econômico e a do político são objeto de divergências no pensamento político desde pelo menos o século XIX, quando Marx enfatizou, de variadas maneiras, os vínculos existentes entre elas. $\mathrm{O}$ entendimento dessas relações de uma maneira determinista, em que o político derivaria do econômico, deu margem a que muitos as desqualificassem, apontando como reducionista qualquer perspectiva de abordagem pautada no reconhecimento de sua importância.

Trata-se, contudo, de vínculo que os autores liberais mais conhecidos dos séculos passados não tinham se preocupado em desfazer. E que se revela de maneira muito clara quando observamos a política contemporânea, ou quando nos voltamos a momentos importantes da história brasileira, tais como os pertinentes às lutas políticas da década de 1860. Os anos iniciais dessa década ficaram conhecidos como momento de uma "ressurreição do liberalismo"1, mas uma pesquisa mais detida mostra que podem ser vistos como de derrota incontornável dos políticos que atuavam defendendo projetos até então chamados de liberais. Na época, liberais que se chamavam "genuínos" protestaram fortemente contra a atuação de antigos conservadores que, ao se autoproclamarem "liberais", roubavam de seus adversários sua bandeira, num processo de violenta exclusão política.

Alguns desses políticos "novos liberais" passaram, mais tarde, a ser considerados como representantes modelares do liberalismo brasileiro do século XIX. É o caso, especialmente, de Tavares Bastos, que atuou como deputado por três legislaturas, e que escreveu obras que são usadas como base 
para a sua consideração como um dos liberais "mais articulados"2 do Império, textos que são tidos como referência para o estudo da história do Brasil. Ao acompanharmos a trajetória de Bastos, encontramos um político cuja obra se apresentava imersa na luta de seu tempo, e na qual fez parte do mencionado grupo de conservadores que se transformaram nos "novos liberais" do final da década ${ }^{3}$. Ao investigarmos essa luta, em diversos momentos, descobrimos a estreita imbricação com os interesses econômicos presentes no mercado. É algo especialmente visível na relação entre a queda do gabinete Olinda, em 1866, e os conflitos em torno da "questão bancária". É esta relação que busco expor a seguir, com base em pesquisa feita nos jornais Correio Mercantil e Jornal do Comércio, e nos debates parlamentares.

\section{Um gabinete em apuros}

Em 29 de junho de 1866, o jornal Correio Mercantil publicou um texto muito revelador, assinado com o pseudônimo Yanke, em que o autor oculto assinala uma dura situação vivenciada pelo gabinete Olinda, empossado em 12 de maio de 1865, e que esteve sempre cindido por grandes divergências. Era mais um dos gabinetes da liga progressista, iniciada no começo da década, entre conservadores moderados e liberais, e que sempre se viu marcada por uma dificuldade muito grande de solidificação. Divergências entre antigos conservadores e liberais, e também entre grupos diferentes dos próprios exconservadores, minavam a possibilidade de uma coligação que fosse estável.

O ministério presidido por Olinda foi denominado "o gabinete das águias", segundo Joaquim Nabuco porque continha em sua formação quatro ex-presidentes de conselho: Olinda $^{4}$ (presidente do conselho e ministro do Império), Ferraz ${ }^{5}$ (Guerra), Nabuco de Araújo $^{6}$ (Justiça) e Saraiva ${ }^{7}$ (Marinha, substituído em 27 de junho por Silveira Lobo). Além deles, 
compunham o ministério Dias de Carvalho ${ }^{8}$ (Fazenda, substituído em março de 1866 por Carrão ${ }^{9}$ ), Otaviano ${ }^{10}$ (nomeado para a pasta de Estrangeiros, mas declinou, sendo substituído por Saraiva) e Paula Sousa ${ }^{11}$ (Agricultura). ${ }^{12}$ Apesar do ministério ter colocado como programa apenas a debelação da guerra, não se propondo a reformas políticas, ${ }^{13}$ não logrou ensejar a união entre as frações dissidentes da liga progressista.

O texto do jornal acima mencionado tratava de uma circunstância em que a situação do gabinete tinha se agravado muito, o que se expressava no fato de que sofria oposição do seu próprio líder na Câmara, Tavares Bastos, que se opunha veementemente à política bancária que o ministro da fazenda, Carrão, visava implementar. Haveria um desentendimento entre o gabinete e a própria maioria que o tinha sustentado, no que concernia a essa "questão momentosa". O título do texto é "A maioria e o gabinete não se entendem", e traz detalhes do debate da Câmara que a transcrição oficial das falas, publicada nos Anais, não fornece:

As explicações que o Sr. Tavares Bastos deu na sessão de 27 deste mês, em relação à proposta do Sr. Ministro da fazenda, e depois o discurso que proferiu em relação ao orçamento do mesmo ministro, provam que há aí alguma coisa de incoerente, há o que quer que seja que demonstra grandes desinteligências entre a maioria e o gabinete.

O Sr. Tavares Bastos esteve sempre em oposição ao Sr. Carrão quanto às idéias bancárias e financeiras; e fazendo dessas desinteligências motivos de recusa das comissões que examinam a referida proposta, pronunciou-se por tal forma que indicou perfeito desacordo com o ministro.

O que significa isto?

É na maioria que está plantada a discórdia; e essa maioria assim apartada do gabinete nos pontos capitais da questão momentosa, está em condições de governar?

Respondam os REGENERADORES do sistema representativo.

No discurso que em referência ao orçamento da fazenda o Sr. Tavares Bastos proferiu em muitas ocasiões mortificou ao Sr. 
Carrão, e a ponto de, diversas vezes, entender-se ao ouvido com o Sr. Saraiva; e quando o Sr. Tavares Bastos falando do senado disse que era necessário - reformá-lo - porque não aceitava as inovações dos projetos liberais de S. Ex., o Sr. Carrão franziu a testa e rosnou - que inconveniência!

$\mathrm{O}$ que significa isto?

Ainda mais, quando o Sr. Tavares Bastos falava o Sr. Ministro da agricultura [Paula Sousa] ria-se e conversava alto, de maneira a interromper o orador, o qual ZANGANDO-SE, pediu que o deixassem falar. $\mathrm{O}$ que respondeu o ministro ninguém ouviu, ou não ouvimos; ouvimos porém, o Sr. Tavares Bastos enraivecido dizer - é desaforo!

Que cordialidade entre os ministros e um membro da maioria! O que haverá aí?

- Será o despacho próximo do TOMBAMENTO dos PORTENTOSOS desta situação MILAGROSA, em que os convertidos se preparam a novos ares e a novos climas?

DICANT PADUANI.

Não ficou nisto. Quando o Sr. Tavares Bastos justificava o seu projeto de liberdade de escravos, e tantas liberdades de palavras, o Sr. Carrão saiu, e foi ROSNANDO coisas que não entendemos.

O que será isto?

- Há coisas inexplicáveis às vezes... depois... depois todo mundo vem a saber.

Entretanto, fala-se que o Sr. Tavares Bastos faz pressão no ânimo do Sr. Carrão para não satisfazer a um pedido do Sr. Senador Dantas ${ }^{14}$ e como o negócio tem sido demorado, o Sr. Tavares Bastos está fazendo cócegas...

Neste mundo há coisas

Sr. Carrão não se deixe lograr [?], faça justiça. ${ }^{15}$

No dia seguinte, Tavares Bastos publica, no mesmo jornal, um artigo defendendo-se, e de modo a ocultar as divergências existentes na "situação", dizendo que o texto de Yanke era "falso", e que não discursou para "hostilizar ao ministério", mas sim com "a convicção formada no calmo estudo dos negócios". ${ }^{16}$ E obteve, em $1^{\circ}$ de julho, uma defesa da sua atuação, por um autor de pseudônimo "um seu patrício": 
Quem é que ignora as idéias do ilustre alagoano sobre finanças?

$\mathrm{S}$. Ex. é contra a tutela, e contra a degolação que se quer fazer às liberdades bancárias e das indústrias. Essas idéias S. Ex. não cede ao governo, pelo que o felicitamos com entusiasmo e franqueza. ${ }^{17}$

Nos debates da Câmara dos deputados do ano de 1866, é possível visualizar com clareza a existência de diferenças entre Tavares Bastos, líder da maioria que apoiava o gabinete Olinda, e o ministro da fazenda, Carrão. $\mathrm{Na}$ atuação do deputado, fica nítido que ele se afina mais com Paula Sousa, ministro da Agricultura, que tinha idéias referentes à questão bancária bem diversas das de seu colega, que apresenta um projeto muito restritivo em relação ao banco do Brasil em abril, ${ }^{18}$ projeto esse que não é sequer debatido na Câmara.

No Correio Mercantil de um mês antes, já ficava claro que a atuação de Bastos sinalizava dissonâncias entre o ministério da fazenda e o deputado que deveria dar-lhe sustentação na Câmara. O comércio do Rio de Janeiro já vivia fazia tempo condições consideradas calamitosas do meio circulante, as quais faziam urgentes providências em relação à emissão de moeda. Depois de muitas dificuldades na sucessão de Dias de Carvalho, que pediu demissão do ministério da fazenda em março, em virtude principalmente dessa situação, Carrão ascendeu ao ministério, em 7 de março. ${ }^{19}$

O gabinete Olinda viveu grandes dificuldades em toda a sessão de 1866. E, antes mesmo de iniciados os trabalhos da Câmara, havia boatos de demissão do ministério, e conflitos intensos entre o ministro da fazenda e a "praça de comércio", segundo artigos publicados no Correio Mercantil. Em 12 de fevereiro, Justus critica o envio, no dia anterior, pela praça de comércio, de um ofício ao ministro da fazenda, Dias de Carvalho, "a propósito da escassez" de trocos miúdos. O autor considera que teria sido melhor ter convocado um meeting, e vê nesse envio uma tentativa de colocar "a entidade governo" em descrédito, transformando a cadeira de ministro em "banco dos 
réus, objeto de horror ou desprezo." ${ }^{20}$ Boatos havia de demissão somente do ministro da fazenda, ou de queda do ministério inteiro, cuja desunião era denunciada todo o tempo: nos textos publicados a pedido no Correio, há a afirmação de que "um laço fatal" prende os ministros "uns aos outros", segurando-os apesar da desarmonia, ${ }^{21}$ e de que o gabinete vive um "estado contínuo de dissolução". ${ }^{22}$

Na Câmara, na eleição da mesa, o ministério é humilhado, ao ter que aceitar oposicionistas no comando da casa legislativa. Teria ficado patente que o gabinete "vê-se coagido a aceitar homens necessariamente oposicionistas". ${ }^{23}$ No dia 20 de março, Pompilio assinala a novidade representada por essa situação, num texto intitulado "O gabinete Olinda": "A crise ministerial, os arrufos não se acabaram; a crise recrudesceu com a eleição da mesa da Câmara dos deputados. A capital presenciou o que nunca ali se viu." O presidente e os dois vice-presidentes da mesa francamente declararam-se oposicionistas; com o que o ministério teria sido "flagelado, triturado". Concluía o autor dizendo que "as pastas se acham vagas." 24

Em 22 de março, Tavares Bastos faz um discurso em que defende algumas idéias referentes à questão bancária, ${ }^{25}$ e entre amigos diz que não está certo de que tais idéias são as do ministro. O procedimento inusitado é sinalizado em texto publicado por Farthing, no Correio Mercantil, em 26 de março. ${ }^{26}$ No dia 31, o mesmo autor comenta a idéia sugerida pelo jornal Diário do Rio, de que o discurso de Bastos seria uma provocação ao ministro:

Sem o crédito que justamente merece a palavra do Diário, ninguém tal acreditaria.

Não. Ninguém acreditaria que um deputado, de quem se diz ser chefe da maioria, viesse assim torturar o ministro, quando ainda não teve tempo de examinar o estado da praça, do banco e do tesouro, para resolver na opção das medidas de que pode lançar mão, aplicáveis à situação peculiar do tesouro, do banco e do comércio. 
(...) Um chefe da maioria não pode deixar de estar de acordo com o ministro: e que o Sr. Tavares Bastos o não estava demonstramno suficientemente os sinais de não-assentimento que lhe deu o Sr. Conselheiro Carrão, mesmo para aqueles que nunca tinham ouvido a S. Ex. enunciar princípios de que não se pode deduzir os corolários que apresentou o Sr. Tavares Bastos no seu discurso $(\ldots) .^{27}$

De fato, bem poderia ser uma provocação ao ministro o discurso de Bastos, ${ }^{28}$ porque em 9 de abril Carrão apresentou à Câmara o projeto da sua lavra, que contemplava a posição da comissão de fazenda do Conselho de Estado. ${ }^{29}$ Estabelecia a fiscalização da emissão e das operações de desconto do banco por parte do governo; previa a substituição de notas do banco por notas do tesouro, etc., ${ }^{30}$ sofrendo a oposição ferrenha da diretoria do banco e de negociantes da praça de comércio do Rio de Janeiro.

A questão bancária se associa a outras na configuração de um ministério muito desunido, desunião que corresponderia à divisão da própria "maioria" que sustentava o gabinete. Daí a oposição de Bastos a Carrão, e aproximação em relação ao ministro da agricultura, Paula Sousa.

Entre as demais questões que também dividem a situação, a concorrência pelas próximas eleições parece a mais candente. Mas existem também a do déficit e a das despesas avultadas com a guerra do Paraguai, um empréstimo suspeito feito em Londres em 1865, a falta de trocos miúdos. Perceber a simultaneidade da presença dessas questões no debate é importante, tendo em vista captar o vínculo íntimo que existiu entre os desdobramentos da política e os interesses econômicos, na experiência dos homens que lutavam na política parlamentar do Império do Brasil naquele momento. 
OS "ABUTRES" NA TURBULÊNCIA DAS "ÁGUIAS"....

\section{A "questão bancária" na "guerra interna": um projeto para "meia dúzia de homens"}

$\mathrm{Na}$ véspera da aprovação do voto de graças no senado, o ministro da Agricultura, Paula Sousa, apresentou na Câmara um projeto referente à questão bancária oposto ao que apresentara o ministro da fazenda, em abril, mas que ficou sem encaminhamento por conta da oposição de seus próprios correligionários, liderados por Tavares Bastos. O novo projeto elevava a emissão do Banco do Brasil até 8.000:000\$000 (oito mil contos de réis) além do triplo do fundo disponível, e autorizava a emissão de até 4.000:000\$000 (quatro mil contos de réis) em notas do tesouro dos valores de $1 \$ 000$ (um mil réis), $2 \$ 000$ (dois mil réis), $5 \$ 000$ (cinco mil réis) e $10 \$ 000$ (dez mil réis). ${ }^{31}$

Esse projeto foi duramente combatido por liberais e conservadores, na Câmara. E Paula Sousa admitiu a verdade da insinuação do conservador Junqueira, de que atenderia interesses particulares, de "meia dúzia de homens", existentes na praça de comércio ${ }^{32}$, dizendo que se tratava de "interesses muito legítimos", de casas bancárias (entre as quais o banco Inglês) em dificuldades, por terem sido atingidas pela repercussão de uma crise que então acontecia na Europa, mas que até aquele momento tinham tido uma atuação muito regular. ${ }^{33}$

O governo precisaria, de qualquer modo, segundo o ministro, fazer o redesconto de seus bilhetes, para "socorrer a praça em apuros". Objeto de discussão poderia existir apenas na fonte da emissão, se o governo ou o banco, optando o ministro por esta última opção, em virtude de que a existência de um prazo para a sua conversibilidade a tornaria mais confiável. ${ }^{34}$

A oposição liberal, na voz de Franco de Almeida, ${ }^{35}$ se opõe à emissão bancária, propondo que o governo redesconte os seus bilhetes com emissão própria, preferível à do banco, segundo o deputado, porque a garantia do banco, lembrada pelo ministro, no fundo, seria o próprio governo. ${ }^{36} \mathrm{O}$ deputado chega a enviar à 
mesa da Câmara uma emenda, autorizando o tesouro a emitir 16.000:000\$000 (dezesseis mil contos de réis) em notas para resgatar os seus bilhetes existentes na praça e no banco do Brasil. $^{37}$

Enquanto na Câmara o ministro da Agricultura, apoiado por uma atuação favorável de Tavares Bastos, defendia, em 13 de junho, os "interesses legítimos muito especiais" ${ }^{38}$ de banqueiros particulares, que seriam favorecidos pelo projeto que pôs em discussão, e que recebeu a oposição intransigente de Franco de Almeida, ${ }^{39}$ no Jornal do Commercio de 13 de junho também era muito atuante a oposição contra o projeto, que mais tarde viria a ser apontado como tendo sido sugerido ao governo por uma fração do próprio comércio ${ }^{40}$ (26 de junho), ou mesmo "ditado" pelos "devedores do banco". Em 15 de julho, "Comerciantes" assinam um artigo com esta última interpretação, monstrando-se indignados com o projeto Paula Sousa:

Casos extraordinários estão sucedendo na nossa praça e nunca vistos em país algum. São hoje em dia os devedores do banco que lhe querem ditar a lei; forte desgraça! Vê-se por todas as ruas e praças gritarem contra o Sr. Ministro da fazenda, e também contra o Sr. de Jequitinhonha, e por quê? Por estes inteligentes funcionários quererem fazer benefícios ao país, e não se continuar a dar o dinheiro do estabelecimento a homens que estão completamente perdidos. ${ }^{41}$

Quando o projeto ainda estava sendo debatido na Câmara, em 13 de junho, alguém com o pseudônimo que está difícil de ler no microfilme do jornal, mas parece ser B. G., publicou um artigo intitulado "O povo e o governo", em que afirma que a proposta de Paula Sousa significava uma "iniqüidade que não tem qualificação", pois contemplava medidas propostas pela praça do Comércio, e viria a favorecer bancos e banqueiros, e "classes" já "privilegiadas", ao mesmo tempo em que 
prejudicaria a "maioria do povo", que sofreria com a desvalorização das notas:

$\mathrm{Eu}$ e como eu centenas de milhares de brasileiros, a imensa maioria da nação, tenho um rendimento certo e invariável, devido ao meu trabalho. A quebra de todos os bancos, banqueiros, de 300 ou 400 comerciantes, de 100 ou 15000 lavradores não me daria, como à imensa maioria do povo, o menor prejuízo; por que [ilegível] obrigar a contribuir para que eles continuem a enriquecer e gozar as delícias da vida, fazendo-nos pagar mais caro tudo quanto precisamos comprar com os nossos vencimentos fixos?

O autor finaliza o texto defendendo a emissão por parte do governo, que implicaria uma distribuição mais eqüitativa do prejuízo:

Se o governo precisa de fundos para continuar a guerra, emita notas suas; será um empréstimo forçado, um imposto a que todo - Brasileiro se sujeitará [ilegível] queixar-se porque será distribuído com [?] e cada um contribuirá na razão das suas despesas. ${ }^{42}$

No mesmo dia, "um pobre" argumenta de modo parecido:

O que não queremos é uma emissão para, à custa dos pobres, de que fazemos parte, refazer a fortuna esbanjada dos perdulários da praça, fortuna que, à custa da sociedade e sem trabalho produtivo pelo país, já haviam adquirido por meio da agiotagem e da usura. ${ }^{43}$

Um terceiro artigo prevê futura encampação, e a "bancarrota geral": 
Se o tesouro necessita de dinheiro, faça o governo uma emissão, e não dê ao banco faculdade de emitir. Esta faculdade é o prelúdio de uma futura encampação [?].

Dizem alguns: é preciso salvar a praça. Isto é um erro.

Em 1864 quis-se salvar a praça, e ficou ela em piores circunstâncias; entretanto o banco passou do duplo ao triplo da emissão.

O banco agora emitirá 10.000.000\$ para salvar a praça, que ficará mais endividada, em 1867 emitirá 20.000.000\$000 para o mesmo fim; em 1868 uns 30.000.000\$000 e assim por diante, até a praça arrebentar com o banco do Brasil, acarretando consigo a bancarrota geral, a ruína do país e de todos. ${ }^{44}$

Havia um conflito entre acionistas e diretores do banco, como sinaliza o artigo "Banco do Brasil", do "Cosmopolita", em 10 de junho de 1866. Propõe a mudança da diretoria, com a aquisição de diretores "com bom senso e conhecedores da praça", para que o banco volte "ao seu antigo estado". Na exposição dos seus argumentos, o autor nos permite divisar conflitos que opunham inclusive a presidência do banco aos seus diretores:

A atual diretoria não preenche tais condições, isto não é novidade para o público, porque está no conhecimento de todos. Os acionistas gritam contra a diretoria, o comércio sensato acompanha-os, e só os únicos que desejam sua conservação são aqueles que andam embrulhados em grande papelório, e que nos tem levado a este estado de coisas...

Outra diretoria que não fosse esta, quando o presidente não quis assinar a ata e retirou-se, pediria imediatamente a sua demissão; mas aquilo é rendoso, e não há nada que os faça deixar os lugares, salvo se todos os acionistas se reunissem e os pusessem fora do estabelecimento, mesmo assim haviam de se agarrar de tal forma que com dificuldade sairiam.

(...)

De que servem reuniões, se nelas não se discute senão os interesses, sofra quem sofrer, porém que a bolsa fique cheia! 
OS "ABUTRES" NA TURBULÊNCIA DAS "ÁGUIAS"....

Finalmente, demita-se a diretoria, e veremos como as cenas mudam $!^{45}$

Os acionistas (representados nas páginas do Jornal do Commercio por "Zangão") se manifestam contrários à emissão por parte do banco, e os diretores (representados por "M. F") favoráveis.

Enquanto no Jornal do Commercio encontram-se muitos artigos contra Paula Sousa, no Correio Mercantil são mais presentes os artigos contra Carrão. Mas não se fazem ausentes também artigos contendo críticas ao aumento da emissão do banco, e mesmo contra a diretoria, tais como o de Little Boy, em 16 de abril. O autor se contrapõe a diretores do banco do Brasil Jeronymo J. Teixeira e Joaquim F. Pinheiro -, que atacaram Sousa Franco por um parecer que este teria dado no conselho de estado, acerca do banco, em que o conselheiro sugere que houve abuso nas emissões do Banco do Brasil, e defende a cassação do direito de emitir daquela instituição. ${ }^{46}$ Tais diretores teriam dito que o conselheiro exprimiria a posição de "interesses despeitados". O autor do artigo exalta-se:

(...) Engano manifesto! Interesses legítimos, sagrados, os interesses dos acionistas que vêem o capital que empregaram naquele estabelecimento minguado e em risco de perda total; interesses do povo e principalmente das classes que recebem vencimentos fixos e que têm entre as mãos um papel depreciado; interesses do comércio, a quem o banco não protege, porque proteger quatro ou cinco indivíduos não é proteger o comércio; interesses do estado, enfim, que carrega toda a responsabilidade da emissão do banco e deseja que digam ao menos qual o algarismo de sua dívida e se ela não aumentará de hoje para amanhã. (destaque feito por mim)

Mais adiante um pouco, o autor insiste na idéia de favorecimento de poucos negociantes, pela emissão do banco: 
Quanto aos arranjos pessoais, permitam S. S. que lhes digamos que foram precipitados. Consta dos livros do banco que mais de metade da emissão bancária atual acha-se em mãos de quatro ou cinco indivíduos cujas letras pejam a carteira. É esta e não pode ser outra a aplicação das palavras do Sr conselheiro Sousa Franco, e deste modo entendidas, confessarão SS. SS. que razão teve o Sr. Conselheiro Sousa Franco para empregar tais expressões $(\ldots)^{47}$

Este e outros artigos revelam que, além de um conflito entre acionistas e diretores do banco, havia uma luta entre frações diferentes dos negociantes, expressa na disputa entre Carrão e Paula Sousa. Se ficamos apenas com os artigos do Correio Mercantil, imaginamos ser Carrão, com seu projeto, um defensor do controle governamental sobre o crédito benfazejo às atividades comerciais, agrícolas e industriais. Em comparação com estes, os artigos publicados no Jornal do Commercio são bastante instigantes pelo contraste de posicionamento. Em 24 de abril, 15 dias após a apresentação do projeto Carrão na Câmara, "Mercador" escreve um artigo em que expõe o boato de que o projeto iria "morrer na comissão de fazenda da Câmara", e se indigna contra essa possibilidade, pois as medidas consignadas na proposta seriam imprescindíveis para restabelecer a confiança, fundamental para a continuidade regular das atividades econômicas: "Toda a demora é nociva ao estado atual, urge que a confiança se restabeleça, e que o poder executivo assuma a sua posição. (...)". O autor diz esperar que o ministro pugne e bata-se por sua proposta: "O país exige de $\mathrm{S}$. Ex. solução desta gravidade, hoje que tudo são receios e confusão." 48

Em 10 de maio, alguém com o pseudônimo de "Luto" não escreve sobre o projeto Carrão, mas sobre a atuação do presidente que escolheu para o Banco do Brasil, nomeação que foi objeto de muitas críticas no Correio Mercantil e no Senado. No texto "Ao Sr. Visconde de Jequitinhonha", que não está inteiramente legível, pode-se ler que o autor apóia o presidente do Banco do Brasil em medidas restritivas que adotava naquele 
momento. Menciona oposição a elas feita pelo jornal Diário do Rio, o qual expressaria, segundo o autor, interesses ofendidos "por efeito das medidas justas que principiaram a ser postas em execução". O autor encoraja o presidente a dar continuidade à sua política, porque ela seria favorável ao "comércio legítimo", em contraposição à "especulação" e à "agiotagem":

Avante, Sr. Visconde, porque, embora alguns [ilegível] gritem contra o que S. Ex. tem feito, o país inteiro o aplaudirá, porque S. Ex. irá conseguir o principal, que é melhorar e tornar mais sólido o nosso legítimo comércio, fazendo desaparecer aquele que só é baseado na especulação e agiotagem.

Acabe-se de uma vez com esses aproveitadores, que sem capital, e só por meio do crédito, querem fazer fortuna. ${ }^{49}$

Na página seguinte, da mesma edição do jornal, um autor com o pseudônimo "1/2 (à esquerda)" também se contrapõe a "meia dúzia" de "abutres": agiotas e usurários que gritam em nome da "praça" inteira:

Dizem os defensores dos abutres que pream as entranhas do comércio e da lavoura, que o procedimento do Sr. Visconde de Jequitinhonha é incompreensível; dizem que o presidente do banco do Brasil não lhes merece confiança; e, [ilegível] declaram que não é a fortuna de cinco ou seis indivíduos que procuram zelar.

Na seqüência, é exposto o procedimento dos adversários de apresentar os seus interesses como se fossem os da "lavoura" ou da "praça" inteira:

O estribilho é sempre o mesmo: a lavoura, a lavoura. O lobo reveste-se da pele do cordeiro e lacrimoso pede misericórdia para mais facilmente devorar o resto do rebanho. 
Fala-se em nome da praça do comércio, quando é sabido e notório que todos os artigos que se tem publicado tanto contra as medidas propostas pelo ministro da fazenda como contra as que o presidente do banco do Brasil está pondo em execução são da pena dos agiotas e usurários ou por eles inspirados.

$\mathrm{Na}$ continuação do artigo o autor afirma que os que se melindram e gritam contra Jequitinhonha são devedores sem nenhuma credibilidade, que não estão em condições de atender a uma exigência mínima, formulada pela própria diretoria [e não pelo presidente] havia "tempos", e apenas posta em execução pelo presidente: a de que a reforma de letras só fosse concedida se o devedor amortizasse 3\% de sua dívida; "note-se bem", acentua o autor, "só três por cento". Com tal resolução a diretoria teria julgado "que era chegada a hora de cessarem esses escândalos inqualificáveis de créditos ilimitados concedidos pelo banco a quem cá fora ninguém empresta um real." Falta de crédito só existiria na praça para especuladores arruinados; quanto aos outros, teriam crédito abundante:

O dinheiro abunda na praça para as firmas que oferecem garantia; às casas de primeira ordem é ele oferecido a um juro inferior ao do banco, as letras do vinho, farinha de trigo, manteiga e outros gêneros a prazo de seis e oito meses são procurados com avidez fora do banco a 7 e 7 1/2\%. O agiota, o usurário e o banqueiro arruinado, esses sim, não podem naturalmente obter fundos dos capitalistas, e por isso é muito natural que bradem [duas palavras pequenas, ilegíveis], e tentem interessar outros para também [uma palavra grande, ilegível] celeuma, procurando fazer crer que o país reprova a proposta do ministro e a energia do presidente do banco.

Enganam-se; o país os conhece e aprecia devidamente.

Prossiga pois o Sr. Ministro; não esmoreça o Sr. Presidente do banco; desprezem ambos as diatribes dos que querem servir-se deste tema para seus fins particulares, porque SS. Ex. têm por si a opinião pública de todo o Império, e contra si somente meia dúzia de especuladores comerciais ou políticos. ${ }^{50}$ 
No dia 12, foi publicado um outro muito interessante artigo, em que tais usurários e agiotas aparecem ligados à lavoura como endossantes de seus títulos. O texto, de autoria de um pseudônimo que não está todo legível, e cuja primeira palavra é "Punhal", começa atacando os diretores do banco (que seriam defendidos pelos "agiotas" como os mais aptos para "apreciarem as contingências da atualidade"), chamando-os de ignorantes em finanças, que não teriam estudado convenientemente por não saberem ler em línguas estrangeiras, e não conseguirem mesmo entender obras escritas em língua portuguesa. Eles é que teriam levado

o banco ao estado quase desesperado em que se acha. Faça-se a lista dos diretores do Banco do Brasil, e digam-nos, com a mão na consciência, se encontram mais de três nomes de homens que sabem alguma coisa de economia política, de finanças. Digamnos quantos dentre eles podem ler um livro que não seja escrito em português; digam-nos quais as obras no nosso idioma em que se pode fazer um estudo dessas ciências; digam-nos quantos diretores podem digerir mesmo o que lêem em português.

As respostas dos acusadores do governo e da presidência do banco "seriam a sua condenação"!

A seguir, são recolocados, com acréscimo de algumas informações importantes (a baixa do juro do banco, conseguida por Jequitinhonha, e a identificação dos "agiotas" como endossantes dos títulos da lavoura), os argumentos do autor do artigo anterior, apontando os interesses particulares dos adversários do ministro da fazenda:

Procura-se iludir o país com devaneios e com artigos em que se procura fazer crer que as medidas decretadas pela diretoria do banco, e postas em prática pelo presidente, têm por fim aniquilar a lavoura, quando a prova mais evidente do contrário é, a baixa do juro do banco, que conseguiu o Sr. Visconde de Jequitinhonha. 
Queixam-se as ventosas que sugam a vida dos lavradores, porque se lhes exige uma amortização de três por cento.

A diretoria do banco, em um acesso de loucura, concedeu créditos de milhares de contos a homens que agora se declaram incapazes de amortizar as suas dívidas, mesmo na razão de três por cento.

Perguntamos agora. De que servem essas firmas, que segundo os estatutos do banco, devem ser de pessoas notoriamente abonadas? Exige o banco um certo número de firmas, somente para que estes recebam uma comissão, ou é para garantir o pagamento da letra no seu vencimento, se o aceitante não a pagar? Em qualquer das duas hipóteses, os endossantes não têm razão de queixa; na primeira, não fazem mais do que restituir aquilo que indebitamente receberam; na segunda, é uma contingência a que se expuseram quando se responsabilizaram pelos títulos que lhes cumpria bem examinar antes de garantir.

Não cercear, portanto, o abuso do crédito nesta ocasião e nestas circunstâncias, fora um abuso econômico, um erro funesto.

Pensem nisto os defensores da virginal candura e sinceridade de vistas dos endossantes das letras da lavoura. ${ }^{51}$

Os devedores não aceitaram amortizar as suas letras a reformar em $3 \%,{ }^{52}$ motivo pelo qual a diretoria, conforme informação de "Nem à esquerda - 0 - nem à direita", "resolve que a taxa para as letras que forem reformadas seja de 3\% mais do que aquela estipulada nos descontos." ${ }^{53}$

Em artigo de 15 de maio, "Agiota" usa o argumento de que os negócios realizados pela diretoria do banco seriam causadores "dos sofrimentos por que estão passando as classes menos abastadas do Império, em conseqüência da perturbação do nosso meio circulante, devida à emissão frenética desse banco", e a seguir deixa bem clara a sua preocupação com a queda das ações do banco, com "a notícia dos últimos desmandos da diretoria", em contraste com a elevação que acontecera com as "medidas postas em execução pelo Sr. Visconde de Jequitinhonha". ${ }^{54}$

Ao que parece, Paula Sousa e Bastos, afinados com os quais estariam os diretores do Banco do Brasil, realmente 
atuariam no sentido de, em detrimento dos interesses de frações significativas do comércio, inclusive dos acionistas do banco, favorecer um pequeno número de banqueiros, possivelmente credores da lavoura, e devedores do Banco do Brasil.

Conforme fica bem claro, o enfrentamento entre tais frações de negociantes se desdobrava em uma das fraturas mais significativas do gabinete Olinda que, conforme os ministros afirmaram depois de sua queda, não pôde se sustentar justamente em razão dessas divergências.

\section{Agradecimento}

Agradeço a Lerice de Castro Garzoni pela gentil e muito competente conversão de páginas microfilmadas dos jornais Correio Mercantil e Jornal do Comércio, por mim pesquisados, em arquivos digitais.

ABREU, Eide Sandra Azevedo. "Vultures" in "eagles"' turbulence: Tavares Bastos, bank question and the struggles in Olinda Cabinet. História, v.28, n.2, p.797-820, 2009.

Abstract: This article focuses the difficulties in wich gabinete Olinda laboured in 1866, and the market's struggles about "bank question". Resulting from research into Jornal do Comércio e Correio Mercantil, as well as Parliamentary debate, it demonstrates that cabinet's members were bound to business groups that were interested in that question.

Keywords: Liberalism - Brazil $-19^{\text {th }}$ century; Brazil - History Empire; Bank question - Brazil $-19^{\text {th }}$ century. 


\section{NOTAS}

1 Ver NABUCO, Joaquim. Um estadista do Império. Apresentação e cronologia de Raymundo Faoro. Posfácio de Evaldo Cabral de Mello. 5. ed. Rio de Janeiro: Topbooks, 1997, v. I, p. 419-423; ; FAORO, Raymundo. Os donos do poder. Porto Alegre: Globo, 1958; v. 2, p. 441497; IGLÉSIAS, Francisco. Vida política, 1848/1868. In: HOLANDA, Sérgio Buarque de, dir. O Brasil monárquico: reações e transações. São Paulo: Difusão Européia do Livro, 1967 (História Geral da Civilização Brasileira, Tomo II, v. 3), p. 80; RÊGO, Walquíria D. Leão. Um liberalismo tardio (Tavares Bastos, reforma e federação). Tese de doutoramento. São Paulo: USP, 1989, p. 56-57; FERREIRA, Gabriela Nunes. Centralização e descentralização no Império: o debate entre Tavares Bastos e Visconde de Uruguai. São Paulo: Departamento de Ciência Política da Universidade de São Paulo; Editora 34, 1999, p. 44.

${ }^{2}$ A expressão é de Wanderley Guilheme dos Santos, conforme citado em RÊGO, Walquíria D. Leão. Tavares Bastos: um liberalismo descompassado. Revista USP. São Paulo, n. 17, p. 74-85, mar./maio 1993, p. 79.

${ }^{3}$ Estudei a trajetória política de Tavares Bastos, e as lutas partidárias em que atuou, no decorrer da década de 1860 e no início da década de 1870, na minha tese de doutoramento O "evangelho" do "comércio universal": o desempenho de Tavares Bastos na liga progressista e no Partido Liberal (1861-1872), defendida em 2004 na Universidade Estadual de Campinas, com a orientação da Prof ${ }^{a}$ Dr $^{a}$ Izabel Andrade Marson.

${ }^{4}$ Pedro de Araújo Lima, Visconde, depois Marquês de Olinda (17931870) - Uma das figuras mais proeminentes do Partido Conservador até a formação da liga progressista, da qual participou. (BLAKE, Augusto Victorino Alves Sacramento. Diccionario Bibliographico Brazileiro. Conselho Federal de Cultura, 1970, $7^{\circ}$ v., p. 16-17).

${ }^{5}$ Ângelo Muniz da Silva Ferraz (1812-1867), futuro barão de Uruguaiana (BLAKE, Augusto Victorino Alves Sacramento. Diccionario Bibliographico Brazileiro, $1^{\circ}$ v., p. 87-88).

6 José Thomaz Nabuco de Araújo (1813-1878) - Originalmente do partido conservador, tornou-se uma das principais lideranças dos conservadores moderados que formaram a Liga Progressista com os liberais e, mais tarde, o "novo" Partido Liberal. 
OS "ABUTRES" NA TURBULÊNCIA DAS "ÁGUIAS"....

${ }^{7}$ José Antonio Saraiva (1823-1895) - Membro inicialmente do Partido Conservador, se tornaria uma das figuras mais proeminentes da Liga Progressista e, posteriormente, do "novo" Partido Liberal. (BLAKE, Augusto Victorino Alves Sacramento. Diccionario Bibliographico Brazileiro, $4^{\circ}$ v., p. 308).

${ }^{8}$ José Pedro Dias de Carvalho (1805-1881), liberal

${ }^{9}$ João da Silva Carrão (1814-1888), liberal

${ }^{10}$ O liberal Francisco Otaviano de Almeida Rosa (1825-1889)

${ }_{11}$ Antonio Francisco de Paula e Sousa, filho de Francisco de Paula Sousa e Melo, personagem que se tornou uma referência na memória liberal.

${ }^{12}$ NABUCO, Joaquim. Um estadista do império (v. I). p. 547

${ }^{13}$ Annaes do Senado do Império do Brasil. Rio de Janeiro: Typographia do Correio Mercantil, 1865, v. I.

14 Manuel Pinto de Sousa Dantas, que viria a ser ministro da Agricultura do gabinete Zacarias de 3 de agosto de 1866 (PEREIRA DA SILVA, João Manuel. Memórias do meu tempo. Introdução de Célio Ricardo Tasinafo. Brasília: Senado Federal, Conselho Editorial, 2003, p. 596)

${ }^{15}$ A maioria e o gabinete não se entendem. Correio Mercantil. Rio de Janeiro, 29 de junho de 1866, p. 2.

16 Correspondências - O Sr. Deputado Tavares Bastos. Correio Mercantil. Rio de Janeiro, 30 de junho de 1866, p. 3.

${ }^{17}$ O Sr. Tavares Bastos. Correio Mercantil. Rio de Janeiro, 01 de julho de 1866, p. 3.

18 Annaes do Parlamento Brazileiro. Câmara dos Srs. Deputados. Rio de Janeiro: Typographia Imperial e Constitucional de J. C. Villeneuve, 1866, tomo 2, p. 75.

${ }^{19}$ NABUCO, Joaquim. Um estadista do Império, v. I, p. 611-612.

${ }^{20}$ A comissão da praça e o Sr. Ministro da fazenda. Correio Mercantil. Rio de Janeiro, 12 de fevereiro de 1866, p. 3.

${ }^{21}$ A situação. Correio Mercantil. Rio de Janeiro, 12 de março de 1866, p. 2.

${ }^{22}$ O programa ministerial. Correio Mercantil, 13 de marco de 1866, p. 3

${ }^{23}$ A atualidade. Correio Mercantil, 13 de março de 1866, p. 2-3.

${ }^{24}$ O gabinete Olinda. Correio Mercantil, 20 de março de 1866, p. 3.

${ }^{25}$ Bastos defendia que não era o momento adequado para adotar a cessação da emissão pelo banco (medida que reputava muito radical), porque haveria uma tendência de melhora das finanças. O estado 
pouco lisonjeiro do banco tinha a ver com as decorrências da crise de setembro de 1864 e com o início da guerra, devendo, portanto, melhorar no futuro próximo. Seria recomendável, então, segundo o discurso de Bastos, adiar a questão do banco, e cuidar do déficit do orçamento (mais de 40.000:000\$), que seria a questão mais urgente. Para fazer face a esse déficit, Bastos propõe que o banco emprestasse ao governo os cerca de 23.000:000\$ em ouro que existiriam em suas caixas, e que o banco emprestasse dinheiro que emitisse, sem juros. Afirmou ser inadmissível o papel-moeda do governo. E defendeu a redução de gastos com armamentos e a supressão de algumas despesas. Também indagou do ministro da fazenda sobre a possibilidade de criação de impostos diretos. (Annaes do Parlamento Brazileiro. Câmara dos Srs. Deputados. Rio de Janeiro: Typographia Imperial e Constitucional de J. C. Villeneuve, 18660, tomo 1, p. 58-60)

${ }^{26}$ A situação financeira. Correio Mercantil. Rio de Janeiro, 26 de março de 1866, p. 2-3.

${ }^{27}$ A situação financeira II. Correio Mercantil. 31 de março de 1866, p. 2.

${ }^{28}$ A relação entre os dois pode ter tido atritos que iam além mesmo dos posicionamentos referentes à questão bancária. No Jornal do Commercio de 15 de maio de 1866, "O abelhudo" publica "Interpelações" ao ministério, entre as quais se encontra uma que sugere que o pai do deputado Tavares Bastos, que era vice-presidente do Rio de Janeiro, estaria sofrendo perseguição política por Carrão: "Será também fato que o Sr. Tavares Bastos [José, o pai], ilustrado vice-presidente do Rio de Janeiro, não é nomeado presidente de $\mathrm{S}$. Paulo, porque o Sr. Ministro da fazenda se opõe?" ("Ao ministério. Interpelações". Jornal do Commercio, 15 de maio de 186, p. 2).

${ }^{29}$ Ver ata do conselho reunido em 19 de fevereiro de 1866, disponível em http://www.senado.gov.br/sf/publicacoes/anais/pdf/ACE/ATAS6Terceiro_Conselho_de_Estado_1865-1867.pdf, p. 28-35.

30 Annaēs do Parlameñto Brazileiro. Câmara dos Srs. Deputados. Rio de Janeiro: Typographia Imperial e Constitucional de J. C. Villeneuve, 1866, tomo 2, p. 75.

31 Annaes do Parlamento Brazileiro. Câmara dos Srs. Deputados. Brasília: Câmara dos Deputados, 1984. Sessão de 1866, v. IV, p. 66.

32 Annaes do Parlamento Brazileiro. Câmara dos Srs. Deputados. Brasília: Câmara dos Deputados, 1984. Sessão de 1866, v. IV, p. 93.

33 Annaes do Parlamento Brazileiro. Câmara dos Srs. Deputados. Brasília: Câmara dos Deputados, 1984. Sessão de 1866, v. IV, p. 111. 
OS "ABUTRES" NA TURBULÊNCIA DAS "ÁGUIAS"....

34 Annaes do Parlamento Brazileiro. Câmara dos Srs. Deputados. Brasília: Câmara dos Deputados, 1984. Sessão de 1866, v. IV, p. 111112.

${ }^{35}$ Tito Franco de Almeida (1829-1899), Liberal.

36 Annaes do Parlamento Brazileiro. Câmara dos Srs. Deputados. Brasília: Câmara dos Deputados, 1984. Sessão de 1866, v. IV, p. 124.

37 Annaes do Parlamento Brazileiro. Câmara dos Srs. Deputados. Brasília: Câmara dos Deputados, 1984. Sessão de 1866, v. IV, p. 124.

38 Annaes do Parlamento Brazileiro. Câmara dos Srs. Deputados. Brasília: Câmara dos Deputados, 1984. Sessão de 1866, v. IV, p. 112.

39 Annaes do Parlamento Brazileiro. Câmara dos Srs. Deputados. Brasília: Câmara dos Deputados, 1984. Sessão de 1866, v. IV, p. 245.

${ }^{40}$ Carta de comerciante ao presidente da comissão da praça que enviou representação ao imperador, na qual era proposta uma nova emissão do banco "como principal medida salvadora da situação.".Segundo o autor da carta, embora a sugestão do comércio tenha sido neste sentido, foi "cruelmente alterada e mutilada", no projeto Paula Sousa. (Jornal do Commercio, 26 de junho de 1866,p. 2)

${ }^{41}$ Banco do Brasil. Jornal do Commercio, 15 de julho de 1866, p. 1.

42 "O povo e o governo". Jornal do Commercio, 13 de junho de 1866, p.

2.

43 "Emissão ilimitada". Jornal do Commercio, 13 de junho de 1866, p. 2.

44 "Papel moeda ou moeda-papel". Jornal do Commercio, 13 de julho de 1866, p. 2.

${ }^{45}$ Banco do Brasil. Jornal do Commercio, 10 de junho de 1866, p.1. 46

Disponível

em:

http://www.senado.gov.br/sf/publicacoes/anais/pdf/ACE/ATAS6-

Terceiro_Conselho_de_Estado_1865-1867.pdf , p. 33-34. Acesso em 30 de novembro de 2006.

${ }^{47}$ Banco do Brasil. Correio Mercantil, 16 de abril de 1866, p. 3.

${ }^{48}$ A proposta do Sr. Ministro da fazenda. Jornal do Comércio. 24 de abril de 1866, p. 2.

${ }^{49}$ Ao Sr. Visconde de Jequitinhonha. Jornal do Commercio. 10 de maio de 1866, p. 1.

${ }^{50}$ Jornal do Commercio, 10 de maio de 1866, p. 2

${ }^{51}$ O Banco do Brasil. Jornal do Commercio, 12 de maio de 1866, p. 2.

${ }^{52}$ Em relação a esta circunstância, "Sempre o mesmo" ironiza, em publicação de 15 de maio: "Os devedores do banco quando lá foram buscar o dinheiro não foi por empréstimo, foi tomado por foro, e por 
isso gritam contra a amortização de 3\%. /Esta lembrança teve-a um profundo pensador saboreando um [ilegível, o nome da bebida] em casa do Carcellei, e o homem tem razão." (Banco do Brasil. Jornal do Commercio. 15 de maio de 1866, p. 2)

${ }^{53}$ Banco do Brasil. Jornal do Commercio. 13 de maio de 1866, p. 2

${ }^{54} \mathrm{O}$ Banco do Brasil e os seus acionistas. Jornal do Commercio. 15 de maio de 1866, p. 2.

Artigo recebido em 06/2009. Aprovado em 09/2009. 